\title{
THEORETICAL JUSTIFICATION OF DESIGN AND TECHNOLOGICAL PARAMETERS OF HULLING MACHINE MAIN WORKING BODIES
}

\author{
Damir Khaliullin ${ }^{1}$, Ildar Badretdinov ${ }^{2}$, Insaf Naficov ${ }^{1}$, Ruslan Lukmanov ${ }^{1}$ \\ ${ }^{1}$ Kazan State Agrarian University, Russia; ${ }^{2}$ Bashkir State Agrarian University, Russia \\ damirtag@mail.ru
}

\begin{abstract}
For many years, the Kazan State Agrarian University has been engaged in research to find new highly effective technical solutions for processing seeds of various crops in the conditions of agricultural producers. One of these developments is a machine for removing the husk from the seed of the aeromechanical type. A distinctive feature of these machines is using in the design an additional working body, made in the form of a mesh confusor, located on the exhaust pipe of the fan-thrower. The aim of the work is mathematical modeling of the movement of achenes in the working areas of aeromechanical devices. The study uses the positions of gas dynamics and analytical geometry. The size and direction of the air flow in the working areas of the seed material are influenced by the geometric parameters of the main working bodies. According to the mathematical solutions, it can be seen that the components of the air flow velocity in the transverse and longitudinal directions change along the length of the confusor. And to determine the parameters of the movement of the achene in the working areas of machines for removing the husk from aeromechanical seeds, it is necessary to know the physical, mechanical and technological properties of seeds, the parameters of the air flow, as well as the structural and technological parameters of the surfaces of the main working bodies. The resulting mathematical models describe the movement of the seed air mixture in the working area, with a numerical solution on a computer you can get a graphical image of the trajectory of the movement of seeds in the confusor, which allows to build a nomogram for calculating the parameters of the confusor and segment, thus justifying the main design and technological parameters of the machine for removing the husk from the seed of the aeromechanical type.
\end{abstract}

Keywords: grain, peeling huller, hulling, aeromechanics, confusor.

\section{Introduction}

Research into new high-efficiency technical solutions for the production and processing of seeds of different crops will be initiated for many years, both in Russia [1-5] and in various countries of America [6] and Eurasia [7-9]. When processing sunflower seeds, one of the important technological operations that determine the quality of the products obtained is peeling - separation of the outer bran of the seed from the core. There are many machines for performing this operation, which differ from each other both in the way of influencing the processed product and in the design features of the working bodies [6-9]. One of these developments is an aeromechanical huller, a distinctive feature of this machine is the use of additional equipment, the design of the working body is made in the form of a mesh confusor, which is located in the exhaust pipe of the fan-thrower [10; 11]. Many scientists have been engaged in theoretical studies of seed movement in the air flow and interaction with working surfaces [12-18]. At the same time, the task of substantiating the design and technological parameters of the mesh confusor that affect the collapse efficiency remains relevant, since little attention is paid to the theoretical study of the interaction of the seed air mixture with its surface. Studies on justification of the optimal opening angles of the confusor were conducted earlier [19].

The aim of the work is a theoretical study of the process of movement of the seed air mixture in the working areas of the aeromechanical huller machine, the interaction of the mixture with the working surfaces of the confusor and construction of appropriate mathematical models.

\section{Materials and methods}

In the study of the movement of the seed air mixture, the provisions of gas dynamics and analytical geometry are used. A significant factor affecting the quality indicators of the process collapsing (hulling) are the forces acting on the seeds in the working area, when they interact with the surfaces of the confusor. They depend on the design parameters of the confusor and on the nature of the air flow. To analyze the trajectory of the seed air mixture and its interaction with the working bodies of the aeromechanical huller, it is necessary to study the scheme of movement of sunflower seeds in the air flow after reflection from the working surfaces of the confusor (Fig.1). Let us consider the differential equation ( 1 and 2 ) of the movement of sunflower seeds in the air flow in a fixed plane coordinate system XOY $[20 ; 21]$ : 


$$
\begin{gathered}
m_{s} \frac{d U_{x}}{d t}=k_{r} F_{s} \rho_{a} \frac{\left|\vartheta_{x}-U_{x}\right|\left(\vartheta_{x}-U_{x}\right)}{2} \\
m_{s} \frac{d U_{y}}{d t}=k_{r} F_{s} \rho_{a} \frac{\left|\vartheta_{y}-U_{y}\right|\left(\vartheta_{y}-U_{y}\right)}{2}-m_{s} g,
\end{gathered}
$$

where $m_{s}-$ mass of one seed, $\mathrm{kg}$;

$F_{\mathrm{c}}$ - area of the mid-section of the seed, $\mathrm{m}^{2}$;

$\rho_{a}$ - density of the air flow, $\mathrm{kg} \cdot \mathrm{m}^{-3}$;

$k_{r}$ - coefficient of resistance of the sunflower seed;

$\vartheta_{x}$ - projection of the air flow velocity on the axis of $\mathrm{OX}, \mathrm{m} \cdot \mathrm{s}^{-1}$;

$U_{y}$ - projection of the seed velocity on the axis of OY, $\mathrm{m} \cdot \mathrm{s}^{-1}$;

$U_{x}$ - projection of the seed velocity on the axis of OX, $\mathrm{m} \cdot \mathrm{s}^{-1}$;

$\vartheta_{y}$ - projection of the air flow velocity on the axis of $\mathrm{OY}, \mathrm{m} \cdot \mathrm{s}^{-1}$;

$g$-acceleration of free fall, $\mathrm{m}^{2} \cdot \mathrm{s}^{-1}$.

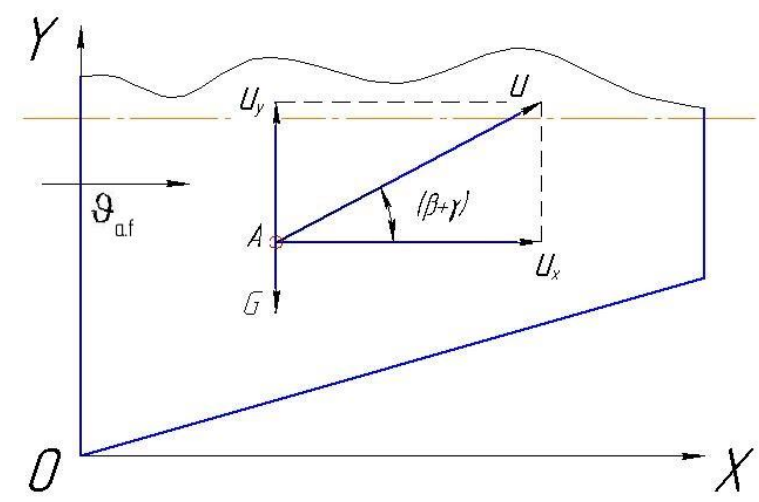

Fig. 1. Analysis of movement of sunflower seed in the confusor of the aeromechanical type huller: $\vartheta_{a . f}$ - velocity of air flow

We solve equations $(1,2)$ taking into account the initial conditions for $t 0=0$ [22]:

$$
\begin{aligned}
& U_{x 0}=A=\frac{k_{r} U_{h} \sin \beta}{\sin \gamma} \cos (\beta+\gamma), \\
& U_{y 0}=B=\frac{k_{r} U_{h} \sin \beta}{\sin \gamma} \sin (\beta+\gamma),
\end{aligned}
$$

where $U_{h}-$ speed of the seed at the moment of impact, $\mathrm{m} \cdot \mathrm{s}^{-1}$;

$k_{r}$ - coefficient of recovery of the seeds at impact;

$\gamma$ - angle between the direction of the speed of the seed and the face of the confusor, degrees;

$\beta$ - angle of opening of the confusor, degress.

Due to the fact that the geometric shape of sunflower seeds is not spherical, then for further calculations we use the concept of equivalent diameter - the diameter of a spherical body, the volume of which is equal to the volume of one seed. In addition, equations 1 and 2 (on the right side) contain the absolute values of the relative seed velocities, and after their conversion, the ratio of the seed velocity and the air flow velocity must be taken into account.

Since the air flow can increase the speed of the seeds, and can also slow them down, then when opening the corresponding modules, we introduce the designation $k_{\mathrm{w}}$-the windage coefficient:

$$
k_{\mathrm{w}}=\mp \frac{3}{4} \frac{k_{r}}{d} \frac{\rho_{a}}{\rho_{s}},
$$

where $\rho_{s}-$ density of seed.

Taking into account the above, equations (1) and (2) will take the form:

$$
\frac{d U_{x}}{d t}=k_{\mathrm{w}}\left(\vartheta_{x}-U_{x}\right)^{2},
$$




$$
\frac{d U_{y}}{d t}=k_{\mathrm{w}}\left(\vartheta_{y}-U_{y}\right)^{2}-g .
$$

When moving sunflower seeds in the air stream, the direction of movement of which coincides with the direction of movement of the seeds, i.e., when $U_{x}<\vartheta_{x}, U_{y}<\vartheta_{y}$ - the windage coefficient takes the sign plus, otherwise-minus. If the air flow velocity is assumed to be constant $\left(\vartheta_{\text {a.f }}=\right.$ const $)$ and directed along the $\mathrm{X}$-axis $\left(\vartheta_{x}=\vartheta_{a . f}, \vartheta_{y}=0\right)$, then equations (6) and (7) are solved analytically.

After integrating equations (6) and (7), we obtain:

$$
\begin{aligned}
& U_{x}=\vartheta_{x}-\frac{\vartheta_{x}-A}{k_{\mathrm{w}} t\left(\vartheta_{x}-A\right)+1}, \\
& U_{y}=\vartheta_{y}-\frac{\vartheta_{y}-B}{k_{\mathrm{w}} t\left(\vartheta_{y}-B\right)+1} .
\end{aligned}
$$

After simple transformations we get a dependence that allows us to calculate the trajectory of the achene:

$$
x=\frac{1}{k_{w}}\left(\ln \left|\frac{1-e^{-y k_{w}}}{k_{w} B}+\frac{1}{A-\vartheta_{a . f}}\right|-\ln \left|\frac{1}{A-\vartheta_{a . f}}\right|\right)+\vartheta_{a . f} \frac{1-e^{-y k_{w}}}{k_{w} B} .
$$

The magnitude and direction of the components of the air flow velocity change along the length of the confusor, depending on its geometric parameters. We investigate the nature of the interaction of the air flow with the faces of the confusor (upper and lower) in a certain cross section $\mathrm{x}$. In this cross section (Fig. 2), the area of interaction of the air flow with the confusor faces is in the intervals from $(x \operatorname{tg} \beta)$ to $(h-2 x \operatorname{tg} \beta)$. Here, the direction of the air flow velocity deviates by a certain angle $\alpha$, which varies from $\beta$ to $-\beta$, and in the central part of the channel is zero [22].

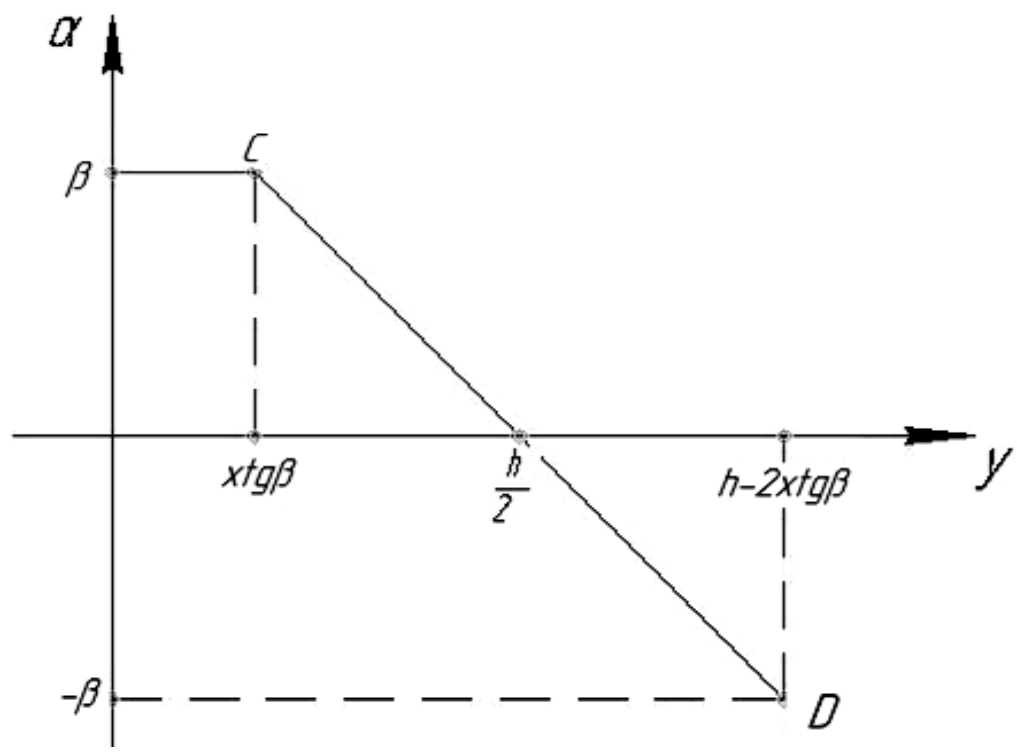

Fig. 2. To determine the values of the angle of inclination of the direction of the air flow velocity

In further calculations, the change in the value of the angle $\alpha$ is assumed to be proportional. Consider a straight line passing through the points $\mathrm{C}$ and $\mathrm{D}$ (Fig. 2) and write down its equation:

$$
\frac{y-x \operatorname{tg} \beta}{h-2 x \operatorname{tg} \beta}=\frac{\alpha-\beta}{-2 \beta} \text {. }
$$

Solving equation (11), we obtain the value of the angle $\alpha$ :

$$
\alpha=\frac{h-2 y}{h-2 x \operatorname{tg} \beta} \beta,
$$

We write down the equations for determining the longitudinal and transverse components of the air flow in the confusor:

$$
\vartheta_{x}=\vartheta(x) \cos \alpha ; \vartheta_{y}=\vartheta(x) \sin \alpha
$$


The narrowing of the confusor channel is necessary to increase the average speed of the air flow moving in it. The change in the average speed of the air flow when moving in the confusor, taking into account its rectangular base, permeable side faces and the constancy of the air flow, can be determined by the following formula:

$$
\vartheta_{h} S_{h}=\vartheta(x) S_{x}+S_{\text {sf }} \vartheta_{a}
$$

where $\vartheta_{h}$ - velocity of the air flow at the base of the confusor, $\mathrm{m} \cdot \mathrm{s}^{-1}$;

$S_{h}$ - cross-sectional area at the base of the confusor, $\mathrm{m}^{2}$;

$\vartheta(x)$ - velocity of the air flow in the confusor at a distance of $x$ from its base, $\mathrm{m} \cdot \mathrm{s}^{-1}$;

$S_{x}$ - cross-sectional area of the confusor at a distance of $x, \mathrm{~m}^{2}$;

$\vartheta_{a}$ - average velocity of the air flow through the side faces of the confusor, $\mathrm{m} \cdot \mathrm{s}^{-1}$;

$S_{\mathrm{sf}}-$ area of the side face of the confusor in the area from its beginning to the point $x, \mathrm{~m}^{2}$.

The flow rate of air passing through the surfaces of the confusor is determined by taking into account its live cross-sectional area:

$$
Q_{a}(x)=\vartheta_{a}(x) x k_{l . s .}\left[h+b+x\left(\operatorname{tg} \beta_{p}+\operatorname{tg} \beta\right)\right] .
$$

where $k_{l . s .}-$ coefficient of the live section;

$h-$ cross-section height at the base of the confusor $\left(h=h_{p}\right.$, where $h_{p}-$ height of the discharge pipe of the throwing fan, $\mathrm{m}$ );

$b$ - width of the base of the confusor $\left(b=B_{p}\right.$, where $B_{p}$ - width of the discharge pipe of the throwing fan, $\mathrm{m}$ ).

Thus, taking into account the impact of the confusor parameters, the components of the air flow velocity can be calculated using the following equations:

$$
\begin{aligned}
& \vartheta_{x}=\frac{\vartheta_{h} b h-S_{s f} \vartheta_{a}}{(h-2 x \operatorname{tg} \beta)\left(b-2 x \operatorname{tg} \beta_{p}\right)} \cos \left(\frac{h-2 y}{h-2 x \operatorname{tg} \beta} \beta\right), \\
& \vartheta_{y}=\frac{\vartheta_{h} b h-S_{s f} \vartheta_{a}}{(h-2 x \operatorname{tg} \beta)\left(b-2 x \operatorname{tg} \beta_{p}\right)} \sin \left(\frac{h-2 y}{h-2 x t g \beta} \beta\right) .
\end{aligned}
$$

\section{Results and discussion}

The analysis of the above shows that the components of the air flow velocity in the transverse and longitudinal directions change along the length of the confusor, depending on its geometric parameters.

Then the mathematical dependencies for determining the parameters of the movement of the achene in the working areas of the aeromechanical huller will be written in the following form:

$$
\begin{aligned}
& \frac{d x}{d t}=\vartheta_{x}-\frac{\vartheta_{x}-A}{k_{\mathrm{w}} t\left(\vartheta_{x}-A\right)+1}, \\
& \frac{d y}{d t}=\vartheta_{y}-\frac{\vartheta_{y}-B}{k_{\mathrm{w}} t\left(\vartheta_{y}-B\right)+1} .
\end{aligned}
$$

These equations can only be solved numerically on a computer using special software that provides a graphical representation of the trajectory of the seeds in the mesh confusor.

As a result of numerical solutions of equations (18) and (19), graphical images of the trajectories of the movement of sunflower seeds are made (Fig. 3).

Thus, the study of the movement of the seed air mixture in the working area of the aeromechanical type of huller and the interaction of the seeds with the working surfaces of the confusor allowed us to obtain the corresponding equations of motion, which made it possible to display the trajectory of the seeds graphically. Analyzing the obtained trajectories of movement of sunflower seeds in the confusor of an aeromechanical type huller, it is necessary to note a decrease in the speed of the movement of seeds at a distance of $0.3 \ldots 0.4 \mathrm{~m}$ from the base of the confusor, and this distance does not depend on the zone of entry of the seeds into the confusor, therefore, the length of the confusor is recommended to be used up to $0.25 \ldots 0.35 \mathrm{~m}$, taking into account the need for the seed to fly out of it and hit the reflective plate in the form of a segment of a sphere. 


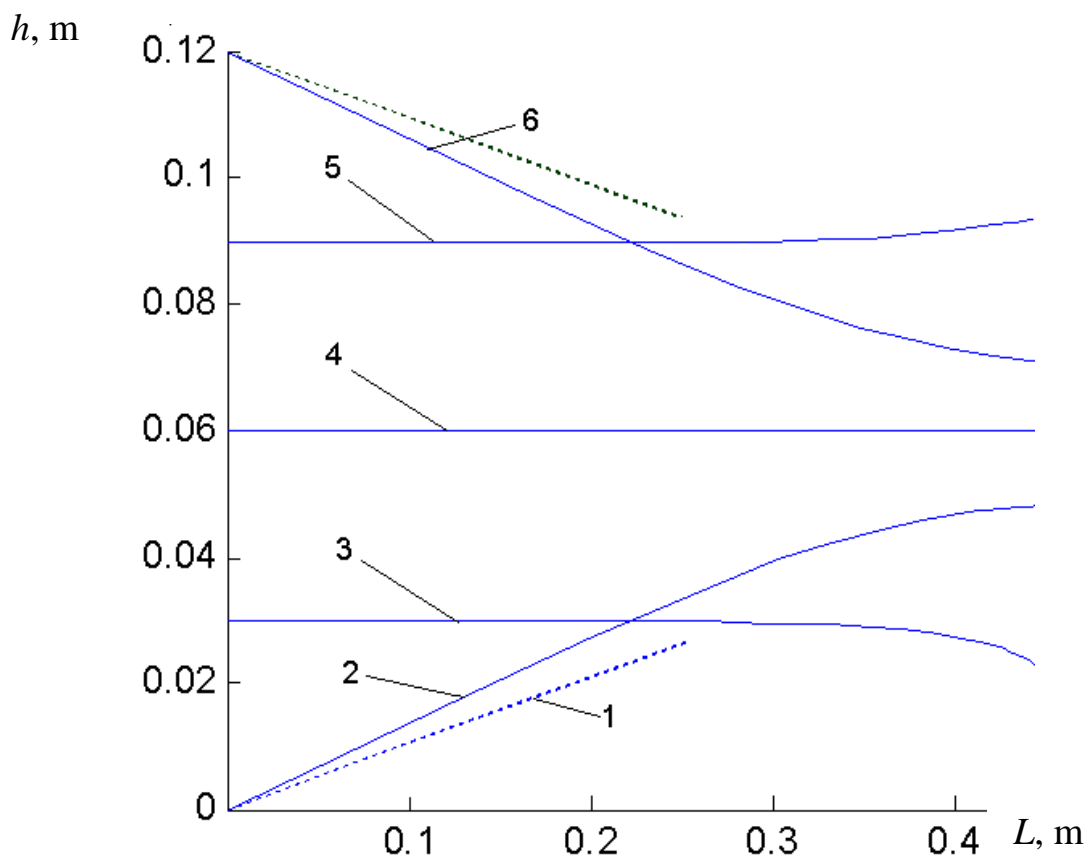

Fig. 3. To determine the length of the confusor: 1 - edges of the confusor; 2 - trajectory of the achene at $\mathrm{h}=0 \mathrm{~m} ; 3$ - trajectory at $h=0.03 \mathrm{~m} ; 4$ - trajectory at $h=0.06 \mathrm{~m}$;

5 - the trajectory at $\mathrm{h}=0.09 \mathrm{~m} ; 6-$ trajectory at $\mathrm{h}=0.12 \mathrm{~m}$

\section{Conclusions}

1. A dependence is obtained that establishes the relationship of the air flow velocity with the design parameters of the confusor and some physical and mechanical properties of sunflower seeds.

2. On the basis of the conducted studies, the dependences characterizing the direction and nature of the movement of sunflower seeds and the air flow in the confusor are obtained.

3. Based on the numerical solution of mathematical models, the graphical representation of the trajectories of sunflower seeds in the working areas of the device allowed us to determine that the length of the confusor of the aeromechanical seed grinder should be within $0.25 \ldots 0.35 \mathrm{~m}$.

\section{References}

[1] Valiev A., Mukhametshin I., Muhamadyarov F., Yarullin F., Pikmullin G. Theoretical substantiation of parameters of rotary subsoil loosener. 18th International Scientific conference "Engineering for Rural Development Proceedings", May 22-24, 2019, Jelgava, Latvia, pp. 312-318.

[2] Khafizov R.N., Khafizov K.A, Nurmiev A.A., Galiev I.G. Optimization of main parameters of tractor and unit for seeding cereal crops with regards to their impact on crop productivity. 17th International Scientific Conference "Engineering for rural development Proceedings", Vol. 17, May 23-25, 2018, Jelgava, Latvia, pp. 168-175.

[3] Galiev I.G., Khafizov K.A, Adigamov N.R., Khusainov R.K. Increase of efficiency of tractors use in agricultural production. 17th International Scientific Conference "Engineering for rural development Proceedings", Vol. 17, May 23-25, 2018, Jelgava, Latvia, pp. 373-377.

[4] N.I. Seomushkin, B.G. Ziganshin, S.M. Yakhin, B.A. Gayfullin, R.E. Vlasov, Mathematical model of interaction of seeds with the internal surface of sowing block of seed drill in Science, Technology and Higher Education. Strategic Studies Institute, 2012, Westwood, Canada, pp. 531-535.

[5] Belinsky A.V. Theoretical investigation of increasing efficiency of combine harvester operation on slopes/A. Belinsky, B. Ziganshin, A. Valiev, D. Haliullin, I. Galiev, N. Adigamov // Engineering for Rural Development. 2019. C. 206-213.

[6] Can. J. Pfant Sci. A dehuller for buckwheat samples. Canadian journal of plant science, vol. 65, 1985, pp. 771-773.

[7] Chandan Solanki, etc. Buckwheat Dehuller and Optimization of Dehulling Parameters. Int.J.Curr.Microbiol.App.Sci., 2018, vol. 7(11): pp. 1041-1052. 
[8] Mar'in V.A., Vereshchagin A.L. Physical principles of processing off-grade buckwheat. Foods and Raw Materials, 2016, vol. 4(1), pp. 51-60.

[9] Kabir A.A., Fedele O.K. A Review of Shelling, Threshing, De-Hulling and Decorticating Machines. J Agri Res, 2018, vol. 3(1), 000148.

[10]Дмитриев А.В., Нуруллин Э.Г. Теоретическое определение энергии шелушения на пневмомеханических шелушителях зерна (Theoretical determination of the desiccant energy on the basis of pneumomechanical grain silencers) Bulletin of Kazan State Agrarian University, 2011, vol. 6.1(19), pp. 101-102. (In Russian).

[11] Mudarisov S., Khasanov E., Rakhimov Z. etc. Specifying Two-Phase Flow in Modeling Pneumatic Systems Performance of Farm Machines. Journal of Mechanical Engineering Research and Developments, vol. 40(4), 2017, pp. 706-715.

[12] Mudarisov S.G., Badretdinov I.D., Rakhimov Z.S. etc. Numerical simulation of two-phase "airseed" flow in the distribution system of the grain seeder. Computers and Electronics in Agriculture, vol. 168, 2020, pp.105151.

[13] Ibyatov R.I. Mathematical modeling of the grain trajectory in the workspace of the sheller with rotating decks/Ravil Ibyatov, Andrey Dmitriev, Bulat Ziganshin, Damir Khaliullin and Alsu Zinnatullina // BIO Web of Conferences 17, 00093 (2020).

[14] Kotov D.N., Isaev Yu.M., Kryuchin N.P. etc. Determination of speed of movement of the particle on the rotating cone with shovels. Int. J. Mech. Eng. Technol., 2019, vol. 10(2), pp. 1507-1514.

[15] Kholpanov L.P., Ibyatov R.I. Mathematical modeling of the dispersed phase dynamics Theoretical Foundations of Chemical Engineering, 2005, vol. 39(2), pp. 190-199.

[16] Нигматулин Р.И. Динамика многофазных сред. Ч.1 (Dynamics of multiphase media. Part 1 . Moscow: Nauka, 1987. 464 p. (In Russian).

[17]Ибятов Р.И., Дмитриев А.В., Лотфуллин Р.Ш. Исследование движения зерна в рабочем пространстве пневмомеханического шелушителя (Grains movement research in the working space of pneumomechanical silencer) Technics and equipment, 2018, vol. 2, pp. 18-21. (In Russian).

[18] Specifying Two-phase flow in modeling pneumatic systems performance of farm machines. Mudarisov, E. Khasanov, Z. Rakhimov, I. Gabitov, I. Badretdinov, I. Farchutdinov, F. Gallyamov, M. Davletshin, R. Aipov, R. Jarullin // Journal of Mechanical Engineering Research and Developments. 2017. T. 40. No.4. C. 706-715.

[19] Халиуллин Д.Т., Нуруллин Э.Г. Исследование движения зерна в конфузоре пневмомеханического обрушивателя семян подсолнечника (Research of grain movement in confusor pneumo-mechanical destruction of sunflower seeds) Bulletin of Kazan State Agrarian University, 2010, vol. 5.4(18), pp. 122-124 (In Russian).

[20] Dmitriev A.V. Study of efficiency of peeling machine with variable deck/Andrey Dmitriev, Bulat Ziganshin, Damir Khaliullin, Alexey Aleshkin // Engineering for rural development. 2020. C. 10531058.

[21]Нуруллин Э.Г. Пневмомеханические шелушители зерна (теория, конструкция, расчет) (Pneumomechanical silencers of grain (theory, construction, calculation)). Kazan: 2011. 308 p. (In Russian).

[22] Халиуллин Д.Т. Исследование движения воздушно-зерновой смеси в рабочей зоне семенорушки аэромеханического типа/Д.Т. Халиуллин, А.В. Дмитриев, Р.Н. Хафизов, М.Н. Яровой (Investigation of the movement of the air-grain mixture in the working area of the aeromechanical type seed plow) Bulletin of Voronezh State Agrarian University. 2019. T. 12. vol. 4 (63), pp. 27-37. (In Russian). 